\title{
The sustainability culture of students of BBS ZFBA
}

\begin{abstract}
The LOHAS (Lifestyle of Health and Sustainability) model represents the consumers of the future, who consider sustainability and responsibility to be important. Global problems and challenges of nowadays are dealt with by purchasers. Therefore, more and more people follow trends that are in connection with the topic of sustainability such as health and environmental awareness, need for the natural, sustainable quality of life as well as search for balance. What features do youngsters have in this field? Our primary research among students of Budapest Business School's Zalaegerszeg Faculty of Business Administration looked for the answers to this question. On the one hand, we examine green thinking and approach, how popular they are, the kind of enthusiasm students show and how responsible they feel for these issues. Based on the results of the survey we intend to conceive the sustainable culture model of ZFBA students and highlight some of its consequences.
\end{abstract}

Keywords: generation $\mathrm{Z}$ and sustainability, environment, sustainable culture, green behaviour

1 Budapest Business School Zalaegerszeg Faculty of Business Administration; e-mail: balazsbence99@outlook.hu.

2 Budapest Business School Zalaegerszeg Faculty of Business Administration; e-mail: mtth206@gmail.com. DOI: http://dx.doi.org/10.31570/Prosp 2019031. 


\section{Cultural sustainability in a theoretical approach}

The connection between the economy and the environment is clear: environmental pollution rises with economic development. For this reason, economic development without environmental considerations can reduce considerably the quality of life for present and future generations. According to Global Footprint Network, an international research organisation, Earth Overshoot Day fell on 1 August the last year, which means that we are using up Earth's resources faster than ever. In other words, humanity is currently using up nature 1.7 times faster than our planet's ecosystem could regenerate it (Earth overshoot 2018).

This green way of thinking is the key to minimise our ecological footprint in order to save our natural assets for future generations. In fact, Generation $\mathrm{Z}$ will have a huge impact on consumer spending from the middle of the 2020s. So the future is up to us! (Lotz Loyalty 2018).

To sum up, recent consumer behaviour surveys have come to the conclusion that consumer societies have groups of people whose values are based on the characteristics of a sustainable lifestyle. A critical consumer leading an active social life is the consumer of the future. This "new type" of consumer-buyer group is called LOHAS (Lifestyle of Health and Sustainability) by professionals. It is important to highlight that such people consider all three pillars of sustainable development (economic, social and ecological) when making shopping decisions. The behavioural patterns of the consumer of the future may include the following factors (Szakály et al. 2015).

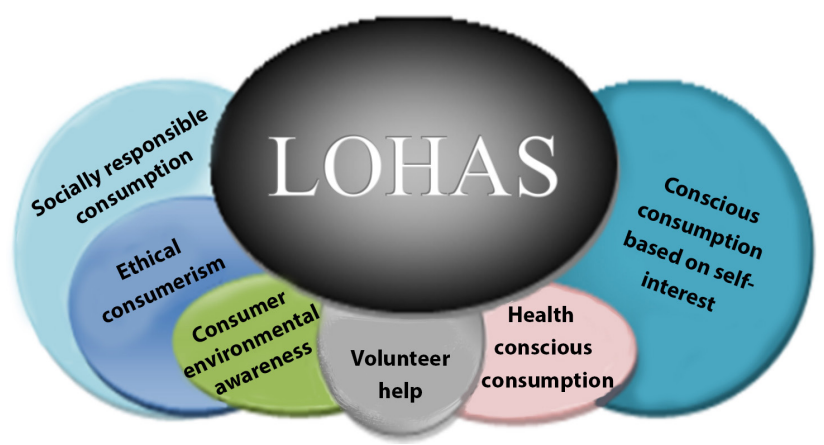


What are the factors behind responsible thinking? This is illustrated by Figure 2:

Figure 2. The model of responsible environmental behaviour

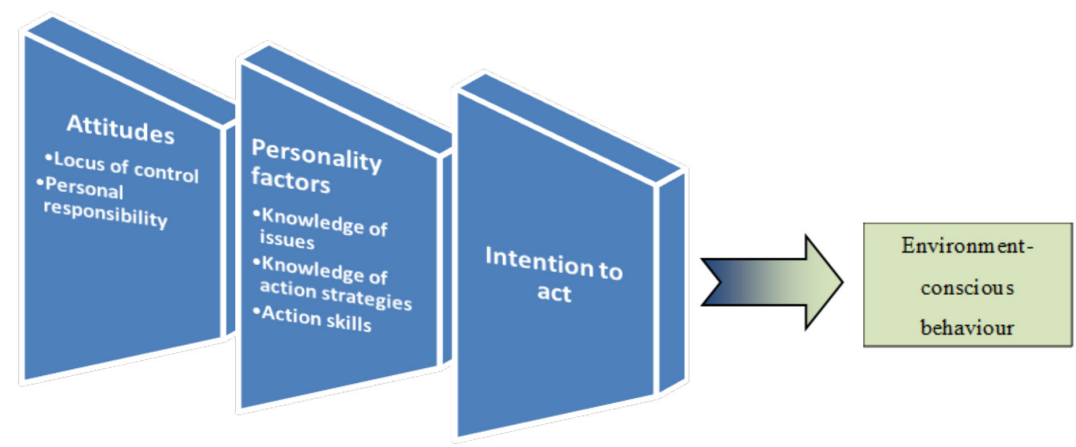

Source: Own edition based on Schäfferné (2008)

Based on the components of this model, we used an online survey to analyse the sustainability culture of students attending BBS ZFBA.

\section{The sustainability culture of students of BBS ZFBA - survey findings}

Our survey was conducted among students of BBS ZFBA and we looked for answers to the following questions:

a) How conscious are students of their own responsibility in connection with the topic of sustainability?

b) What pattern do their family show in relation to sustainability?

c) How solid would they judge their knowledge in the field of sustainability issues?

d) How much do they worry about environmental problems and sustainability challenges?

e) How important are sustainability solutions to them? What are their ambitions and motivations?

f) How do these decisions appear in their achievements?

g) How do they consider the ambitions and solutions of BBS ZFBA? 
In our online research we used quantitative techniques, which helped to quantify data and also allowed for a statistical analysis. The research was carried out with selfadministered online questionnaires. The target group was full-time and correspondence students of BBS ZFBA and its interval was between 18th of March and 2nd of April 2019. Until this period we managed to achieve altogether 152 responses.

We collected data using the following procedure: We reached the students via the Neptun higher education software or in person. We used the questionnaire design template kerdoivem.hu.

\section{The results of the survey}

According to demographic data, $60 \%$ of the respondents were women and $40 \%$ of them were men. The highest qualifications of our university students were really diverse. The majority of the students possess either a secondary school or a vocational school diploma. $15 \%$ of the people questioned dispose of National Qualification Register qualification. As to the residential patterns, $40 \%$ of the respondents live in a county seat or in villages. An additional $20 \%$ of students live in a town. $65 \%$ of the respondents live in a house, while 22 students live in block of flats, plus 30 people have an apartment house. Regarding the faculties, we managed to reach about $40 \%$ of students both in Business administration management and in Finance and accountancy programmes. All students of the university's finance master programme filled out our questionnaire, while only $10 \%$ of the students of the Business Information Technology programme did the same. The total number of respondents justifies that we have to develop a lot as regards the sustainable approach. We believe that our fellow students did not feel the value of their responses which they could have helped our work with.

The results of the answers given to the topic-specific questions are presented in the iceberg model below which simultaneously demonstrates the sustainability culture model.

The invisible part of the iceberg represents our attitudes, values, our individual characteristics. To the last question an average score of 4.4 was reached, which means that the students of BBS ZFBA seem to feel responsibility for sustainability issues. Answers to a similar question show that these issues are also important to respondents' families as scores higher than four were the most often given to this question. 
Figure 3. Sustainability culture model

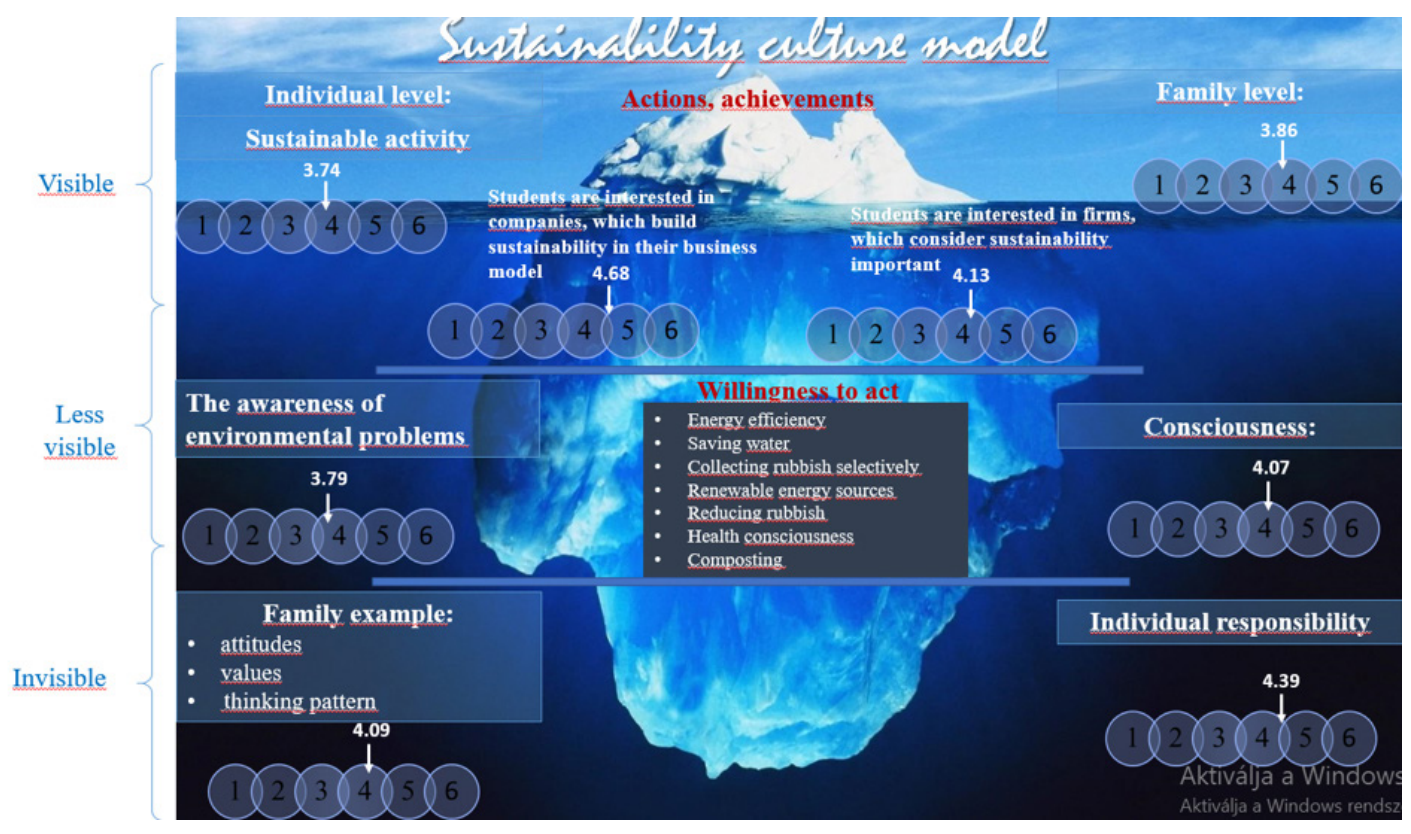

Source: Own edition based on our survey

The less visible part of the iceberg represents respondents' willingness to act as well as their knowledge and consciousness about issues of sustainability. The students estimate both their knowledge and consciousness in connection with sustainability in a similar way. Besides, we also examined the students' willingness to act in connection with sustainability. Most students underlined the importance of energy efficiency, saving water, separate waste collection, using renewable energy sources, reducing waste and being health conscious. As to the willingness to act, the same trends apply, except that doing sports has a growing popularity. Based on our research we can conclude that composting, organic farming, and taking part in volunteer programmes are seen by students as less important. In the visible part of the iceberg, actions and achievements analysed both at family and individual level can be seen. It is clear that university students are more and more interested in firms that consider sustainability as a primary goal and which have already built it in into their business model.

In conclusion, it is also important to emphasise that the majority of the students appreciate the ambitions of and the solutions provided by BBS ZFBA. They also believe that the university's practice has affected their behaviour and attitudes towards the issue of sustainability (scores of 4.5 and 3.8 respectively). 


\section{Conclusion}

The BBS ZFBA students' sustainability culture model reflects that we should move from the less visible level, and try to reach the top of the iceberg. This process is timeconsuming as we have to build the necessary competences and find the motivation. Students need education and experience to reach an even more conscious level of understanding. To achieve this, initiatives of BBS can be useful and effective. Young consumers play a crucial role in this process. Those who follow world news could have experienced the winds of change:

"Hundreds of thousands of young people skipped school across the globe on March 15th, 2019 to march through the streets for an international day of student protests aimed at pushing world leaders into action on climate change." Let us not forget that there is no Planet B!

\section{References}

Baker, A. (2008). The growth of LOHAS internationally. LOHAS Journal, Spring. http://www.lohas.com/sites/default/files/lohasintrntlgrowth sm.pdf. Downloaded: 16.03.2019.

Earth overshoot day 2018 is August 1. Partners around the world to join \#movethedate live stream. https://www.overshootday.org/newsroom/press-release-july-2018-eng$\underline{\text { lish/. }}$.

Euronews (2019). Climate strikes: Students in 123 countries take part in marches. https://www.euronews.com/2019/03/15/climate-strike-school-students-from-over120 -countries-march-to-change-history.

Lotz Loyalty (2018). The future of loyalty programs. https://medium.com/lotzloyalty/ the-future-of-loyalty-programs-d13de71159c5. Downloaded: 14.06.2018.

Nádas Nikoletta - Lukovics Miklós - Udvari Beáta (2017). Új generációs kutatónemzedék és a felelösségteljes innováció. SZTE Gazdaságtudományi Kar Közleményei, (14)1, 283-296. http://acta.bibl.u-szeged.hu/49716/1/gtk 2017 283-296.pdf. Downloaded: 16.03.2019. 
Report of the World Commission on Environment and Development (1987). Our common future. http://www.un-documents.net/our-common-future.pdf. Downloaded: 20.03.2019.

Schäfferné Dudás Katalin (2008). A környezettudatosság többszintű értelmezése és a környezettudatos fogyasztói magatartás vizsgálata. PhD Thesis. Pécsi Tudományegyetem Közgazdaságtudományi Kar Gazdálkodástani Doktori Iskola. https:// pea.lib.pte.hu/bitstream/handle/pea/15247/schafferne-dudas-katalin-phd-2008. pdf? sequence $=1$ \&amp;isAllowed $=\mathrm{y}$. Downloaded: 10.03.2019.

Szakály Zoltán - Pető Károly - Popp József - Jasák Helga (2015). A fenntartható fogyasztás iránt elkötelezett fogyasztói csoport: A LOHAS szegmens jellemzői. (The characteristics of the LOHAS segment: The consumer group which is devoted to sustainable consumption) Táplálkozásmarketing - The Hungarian Journal of Nutrition Marketing, (2)1, 4-5. https://doi.org/10.20494/tm/2/1/1.

Yale Program on Climate Change Communication (2018). Climate change in the American mind. December. http://climatecommunication.yale.edu/wp-content/ uploads/2019/01/Climate-Change-American-Mind-December-2018.pdf. Downloaded: 23.03.2019. 